Emina M. Kopas-Vukašinović University of Kragujevac Faculty of Education in Jagodina Department for Human Sciences

Vera M. Savić

Department for Philology
УДК 373.211.24:378.147

https://doi.org/10.18485/uzdanica.2020.17.1.16

Прегледни рад

Примљен: 10. фебруар 2020.

Прихваћен: 11. мај 2020.

\title{
DESIGNING CURRICULUM CONTENT AS A FACTOR OF EDUCATION QUALITY
}

Abstract: Designing curriculum content includes the development of modern strategies for teaching and learning in the context of developing an individual's ability to think, explore, learn through activity and express own creative potentials. The aim of the paper was to determine whether student teachers recognize the importance of designing teaching contents (DTC) in the educational process. The data was collected through a focus group interview with student teachers of master studies at the Faculty of Education, University of Kragujevac, Jagodina (Serbia). The student teachers' views on the quality of university teaching clearly point to their need and willingness to design curriculum content for more efficient teaching, and stress the significance of DTC for enhancing the quality of education.

Keywords: cooperative learning, thematic linking of contents, appropriate feedback, standards in higher education, knowledge management system.

\section{INTRODUCTION}

The quality of contemporary education is determined by the specific role of those who teach (from pre-school teachers to university teachers) and learners (children, primary, secondary and university students). These roles are numerous, from clearly defining and understanding educational goals, through designing and integrating teaching contents in collaboration, to self-regulation and self-reflection of all participants in the educational process. In the system of formal education, these roles are determined at different levels, from strategic directions at the national and international levels, to curriculum functions and principles that must be respected while working with children and young people. The quality of contemporary university education can be monitored and evaluated on the basis of achieving the aforementioned roles. Scientifically based theory of education confirms the importance and necessity of realising these goals and gives us the answer to the question of WHY it is necessary to achieve them (in order to raise the quality of acquired knowledge and efficiency of education). Also, different methodological 
approaches applied in the implementation of teaching, and teaching practice itself, respond to the question of HOW to achieve the aforementioned roles in order to achieve the determined goal. In the relationship of theoretical and practical knowledge and abilities applied to enhance the effectiveness of teaching, it is possible to find the factors influencing the quality of contemporary education.

The selection and designing of curriculum content is an essential variable of the quality of teaching. The concretisation of this variable of modern teaching should be tracked on two levels. The first one is the interpretation of theoretical assumptions for the definition and achievement of concretisation. The second level is determined by recognising the importance of concretisation for practice in the system of university teaching by student teachers, who are being educated to teach. It is to be expected that during their schooling student teachers realize the importance of designing the curriculum, and then get adequate training to perform it in practice in their future profession.

\section{THEORETICAL BACKGROUND: DESIGNING CURRICULUM CONTENT AS A REQUIREMENT AND A NEED}

In contemporary pedagogical literature and strategic directions of education development, requirements for teachers for the development of students' ability for cooperative learning are clearly highlighted. These abilities include reaching the level of instrumental and emotional independence, the development of students' self-esteem and their readiness for the timely cultivation of emotions. When considering the system of university education, studies have confirmed that university students possess the ability to control their own learning opportunities and achievements and that these abilities are determined by their self-esteem and belief in their own strength (Artelt, Baumert, Julius-McElvany, Peschar 2003). The mission of contemporary higher education implies a reform aimed at developing higher quality learning outcomes. In the center of the action is to strengthen the professional capacity of student teachers by introducing new approaches to teaching and learning, by providing effective support to students, and by supporting meaningful development and guiding of curricula focused on strengthening the students' potential (Hébert, Hartley 2006; The Bologna Process 2020 2009).

Theoretical considerations of the learning outcomes in higher education highlight the assumption that the quality of university education implies the applicability of acquired knowledge and the possibility of its transfer into practice. This assumption means making the requirements placed before teachers more complex, according to the established standards for quality assurance and teacher competencies for the organization of quality teaching, all with the aim of encouraging "dynamic intellectual and educational activities" (Standardi $i$ smjernice za osiguranje kvaliteta 2005: 12). The achievement of this goal involves systemic and meaning- 
ful designing of curriculum content and integration of its complex structures. This would create conditions in which pupils (university students) would be encouraged to learn actively, and to develop and express their own cognitive and creative potentials. In these circumstances, it is possible to develop a knowledge management system, in which an individual will be ready to transform his/her implicit knowledge into explicit knowledge, thus contributing to the transfer of acquired knowledge and its application in practice (Mirkov 2013).

In order to gain a more comprehensive view of the significance of designing teaching contents in the context of the quality of education and its outcomes, we have presented the expected processes and effects of this type of teacher activity schematically (see Scheme 1).

Sheme 1. Designing Curriculum Content

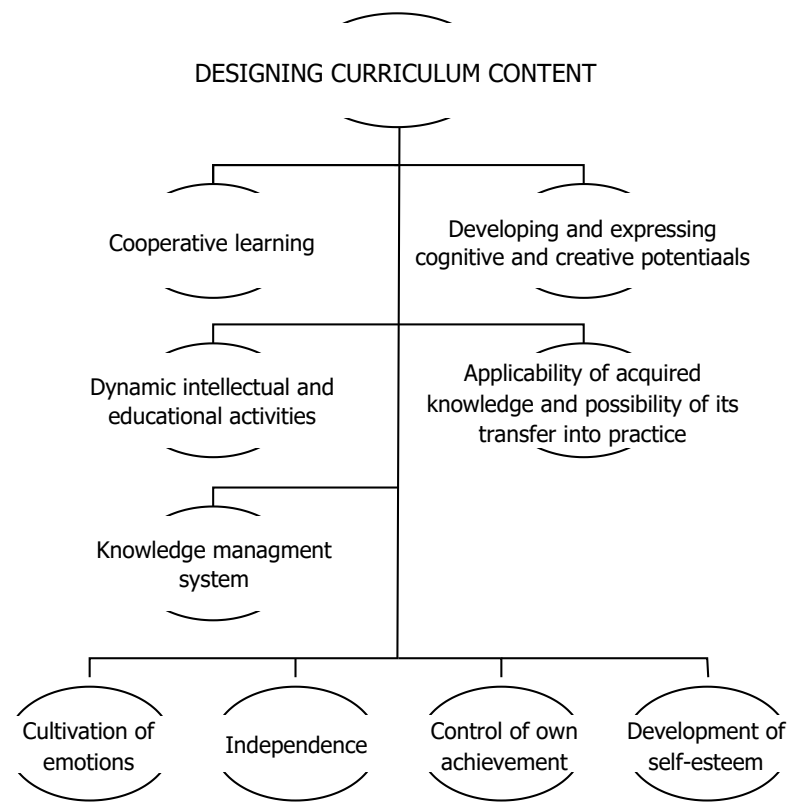

It is clear that designing curriculum content in the system of contemporary education is a requirement, but at the same time it is a professional challenge for teachers. Teachers should, in a quality manner appropriate and acceptable for learners, structure, connect, and teach the content in accordance with available resources, possibilities, and their own interests, as well as in compliance with the curriculum requirements and the possibilities of connecting the knowledge and applying it in new situations (Kopas-Vukašinović, Golubović-Ilić 2017). Also, designing curriculum content is the need and the assumption for developing, expressing and directing cognitive abilities and creative potential of individuals (pupils, university 
students), for cultivating their emotions, and developing and nurturing the capacity for teamwork. These assumptions, in relation to those who teach and those who learn, are a prerequisite for quality assurance in educational institutions, from preschool to university levels. Pupils and university students are provided with learning and support opportunities in their development and progress, and the criteria for testing and evaluating their knowledge are clearly established. At the same time, the conditions for raising the quality of knowledge and periodic review of the curricula being applied are systemically established, to be harmonized with European standards, with the efficient use of all available resources for learning and support to pupils and university students (Spasić et al. 2002).

Designing and integrating curriculum content involves the development of modern strategies for teaching and learning in the context of the development of an individual's ability to think, reason and associate, explore, learn through activity and through attempts and mistakes, and to direct and express own creative potentials (Desinan 2011; Kopas-Vukašinović 2014; Milovanović, Kopas-Vukašinović 2017; Savić 2012). These conditions contribute to the development of acceptable behaviour of pupils / university students and their effective relationship with teachers, which affects the realisation of mutual achievements in the teaching process (Gordon 2008).

Curriculum content prescribes what learners are expected to learn (know, understand and be able to do), but designing an appropriate curriculum content poses a great challenge to the teacher in terms of selecting the content that is meaningful, based on learners' interests and needs, and that involves more than just learning facts (UNESCO 2004). The curriculum content should, therefore, consider the learners' prior knowledge, experiences, and learning profiles, and enable successful implementation of the teaching process in terms of making an impact (Hattie 2015). Research indicates that the most critical factor of effective teaching is teachers' mind frame, i.e. their "ways of thinking about teaching and learning" (Hattie 2015: 81). Eight critical mind frames of effective teachers have been identified by meta-analyses of 1200 research studies, the first being related to the teachers' impact, and the other seven closely related to this one, thus stressing the need for the teachers' continual evaluation of the influence of their teaching on the learners' learning (Hattie 2015).

In higher education studies it has been found that effectiveness results from "the ways teachers, irrespective of method of delivery, make their success criteria clear, the degree of challenge and feedback, and the quality of the interactions among students and between students and the teacher" (Hattie 2015: 86). As a consequence, training future teachers for the demanding roles in their professional careers requires a high quality university programme. The role of teacher training curriculum content in shaping teachers' cognitions has been confirmed by a number of studies (Ellis, Read 2015; McLaughlin 2012). To determine how training manages to influence teaching practice over a period of time, it is important to conduct 
re-evaluation of initial training. Moreover, teacher cognition, i.e. understanding of teachers' attitudes, knowledge and beliefs, and how these notions relate to teachers' actual practice, should be studied in order to determine the relationship between theory and actual practice (Ellis, Read 2015). When student teachers begin their pre-service training they all hold beliefs about teachers and teaching on the basis of teachers' actions rather than on their plans or thoughts, being more influenced by the teachers' personalities and personal qualities than by their teaching expertise or skills (McLaughlin 2012). Teachers' cognitions are rooted in their teaching context, training and experience, but generally there is a tension between what teachers think and do that is caused by not addressing or evaluating the initial beliefs of student teachers within a teacher training curriculum (McLaughlin 2012). It is, therefore, important to ensure in teacher training that pre-service teachers understand how their beliefs develop and how they can interfere with their teaching, and to prepare them to avoid a misconception that what they say is what they do (McLaughlin 2012). In sum, the studies have emphasized the influence of training on what teachers think, in particular, and on the quality of education, in general.

\section{METHODOLOGY}

The subject of our research is the quality of university education and the ability of teachers at all levels of education to design teaching content in order to improve the quality of education in general. This research was aimed at determining whether student teachers, based on acquired didactic-methodological knowledge, recognize the importance of designing teaching contents (DTC) in the system of professional competencies of teachers in the educational process. This aim was realized through two research tasks: 1) to determine whether and how student teachers understand the concept of DTC; 2) to examine whether student teachers recognize the concept of DTC as a factor of quality of university teaching and of professional competencies of teachers. In relation to the first task, the student teachers who stated that they understood the concept of DTC also had to provide its definition. In relation to the second task, they had to list up to five main factors of quality teaching and of professional competencies of teachers, based on which we discerned the extent to which these variables also imply the elements of DTC. Two research hypotheses were determined in relation to the established research tasks: 1) starting from the fact that the student teachers in focus groups had, during their graduate studies, passed exams and mastered psychological, pedagogical and didactic and methodical knowledge and skills, the first assumption was that they had a good understanding of the concept of DTC and that they were able to define its factors; 2) the second assumption was that student teachers recognized the concept of DTC as a factor of quality of university teaching and of professional competencies of teachers. 
The research utilized the descriptive method and the procedure of content analysis. The data were collected on the basis of discussions with students of master academic studies of the Faculty of Education of the University of Kragujevac in Jagodina (Serbia), Department for Preschool Teachers $(\mathrm{N}=53)$. The students were divided into four focus groups. The research was conducted in the period April-May 2017.

\section{RESEARCH RESULTS AND DISCUSSION: STUDENT TEACHERS' VIEWS ON DESIGNING CURRICULUM CONTENTS AS A FACTOR OF EDUCATION QUALITY}

The first research task aimed to examine whether and how student teachers understood the concept of DTC. The quality of teaching activities assumes a special dimension while working with university students in situations when we educate future teachers. Knowing how they view and estimate the quality of university education and how much they recognize the importance of teachers' competencies for designing curriculum contents, are the assumptions of their readiness for performing quality and effective teaching in the future. At the same time, the survey of the student teachers' views indicates the quality of current university education and opportunities for its improvement. In this context, the results we have obtained on the basis of qualitative data collected about the factors affecting the quality of university education are significant.

The student teachers had, during their undergraduate studies, passed exams and acquired the psychological, pedagogical and didactic-methodological knowledge and skills, which was our starting assumption in the study; moreover, they had learned and mastered the concept of designing curriculum contents (DCC), and could recognize it as a benchmark of the quality of university education. Answering the question of whether and how they understood the concept of DCC, all respondents pointed out that they understood this concept (fully or partially). As evidence, the respondents defined the term of DCC in the following ways:

- quality distribution of curriculum contents that enables pupils and students to easily associate the material and master these contents;

- planning, organization, and classification of curriculum contents according to their importance, significance, and relevance;

- linking of curriculum content for better understanding and application of acquired knowledge;

- the sequence of processing curriculum content, which allows the development of causal connection skills;

- thematic linking of curriculum contents, the selection of relevant information compared to available information. 
In relation to the first research task that aimed to determine whether and how student teachers understood the concept of designing teaching contents, and in order to achieve a better overview of these results and their relation to the theoretical approach to the problem, the responses and main factors of DTC are presented in the form of a table (Table 1).

Table 1. Students' views about DCC and theoretical background

\begin{tabular}{ll}
\hline \multicolumn{1}{c}{ Designing Curriculum Content } \\
\hline \multicolumn{1}{c}{ Students about DCC } & \multicolumn{1}{c}{ Theoretical Background DCC } \\
\hline $\begin{array}{l}\text { Quality distribution of curriculum contents } \\
\text { Planning, organization, and classification curriculum } \\
\text { contents }\end{array}$ & $\begin{array}{l}\text { Dynamic intellectual and educational activities } \\
\text { Developing and expressing cognitive and creative of } \\
\text { potentials } \\
\text { Thematic linking of curriculum contents }\end{array}$ \\
$\begin{array}{l}\text { The sequence of processing curriculum } \\
\text { The posility of transfer of acquired knowledge }\end{array}$ \\
\hline
\end{tabular}

The respondents' responses emphasise the basic factors of not only the DCC concept but also the quality of university teaching, presented in the first part of this paper (the applicability of acquired knowledge, the possibility of its transfer into practice, active learning, etc.). These factors highlight the common roles of those who teach (teachers) and those who learn (pupils, university students) as planners, organizers, implementers, and evaluators of teaching activities. Here the priority is given to the teacher, who is the initiator of joint activities in structuring the curriculum contents.

Based on student teachers' responses in relation to the first research task, it can be concluded that the first research hypothesis has been confirmed, that student teachers had a good understanding of the concept of DTC and that they were able to define its factors.

The second research task aimed to examine whether student teachers recognized the concept of DTC as a factor of the quality of university teaching and of professional competencies of teachers.

In determining the factors of quality teaching, the respondents in the focus groups clearly highlighted the importance and necessity of the ability of teachers to design curriculum content. The respondents were given the task to list up to five main factors of quality teaching. According to their views, the quality of teaching can be recognized based on the following indicators:

- plan-guided lessons;

- well-organised lessons;

- connecting and aligning curriculum content with a teaching unit and the objectives of the lesson, well-structured content; 
- the ability of teachers to stress, present, link and systematize the most relevant curriculum contents;

- connecting theoretical contents with practical experiences;

- interactive teaching (pupil-pupil and pupil-teacher) and encouraging pupils to take part in the classroom activities;

- diversity in the implementation of teaching forms, methods, tools and materials and their combination;

- motivation and commitment of pupils for engaging actively in lessons, and the adequacy of adapting curriculum contents to pupils' abilities;

- modernization of teaching using modern technology;

- timely and appropriate feedback;

- the ability of university teachers to introduce student teachers to research activities.

The above statements also stress the factors that directly refer to the ability of teachers to design curriculum content or are indirectly linked to this requirement. Direct factors include the requirements for connecting and aligning the curriculum content with a teaching unit and the objectives of a lesson, for effective content structuring, as well as for the ability of teachers to point out, adequately present, link and systematize the most relevant contents. Quality teaching implies the ability of teachers to connect theoretical contents with practical experiences, and to process them in accordance with pupils' (university students') abilities. Indirect factors can be recognized in the following factors of quality teaching: plan-guided lessons; well-organised lessons; encouraging pupils to take part in classroom activities, diversity in implementation of teaching forms, methods, tools and materials and introducing university students to research activities. These factors, viewed in this context, include the ability of teachers to effectively design and integrate curriculum contents so that pupils (or university students) can acquire them more easily and successfully.

The above views of student teachers on the quality of university teaching clearly point to the need and significance of teachers' willingness to design curriculum content for more meaningful and more efficient teaching. This benchmark of modern education is, consequently, one of the priority tasks and requirements for teachers.

Based on student teachers' responses it can be concluded that the second research hypothesis has also been confirmed, that students recognize the concept of DTC as a factor of quality of university teaching and of professional competencies of teachers. 


\section{CONCLUSION}

In the system of modern education, the ability of teachers to design curriculum content is a prerequisite for quality teaching. The theoretical context of this problem is determined primarily by pedagogical, psychological and didacticmethodical scientific findings. These findings represent a starting point for determining the strategic directions for developing education and ensuring its quality at national and international levels. In pedagogical practice, designing curriculum contents is recognized by students as a benchmark of quality of university teaching and teachers' competence. Of particular importance is the fact that recognition of its value by student teachers can, in a way, be defined as an assumption of their competencies for future occupation and work with children (pupils). The fact that they recognize the importance of teachers' abilities to properly plan, organize, classify and link curriculum contents indicates their willingness to develop own abilities for designing curriculum contents in their future work, with the aim of achieving the best possible professional results.

\section{REFERENCES}

Artelt, Baumert, McElvany, Peschar (2003): Cordula Artelt, Jurgen Baumert, Nele McElvany, Julijen L. Peschar, Learners for Life: Student Approaches to Learning, Results from PISA 2000, OECD, Organisation for Economic Co-operation and Development. Retrieved in January 2019 from https://www.oecd.org/edu/school/programmeforinternationalstudentassessmentpisa/33690476.pdf

Desinan (2011). Claudio Desinan, Current teaching and learning strategies, In: Vladimir Kadum (Ed.), Suvremene strategije učenja i poučavanja, Pula: Univerzitet Jurja Dobrile, 583-590.

Ellis, Read (2015). Gail Ellis, Carol Read, Course Design and Evaluation in Primary Teacher Education, In: Christiana Nicole Giannikas, Lou McLaughlin, Gemma Fanning, Nellie Deutsch Muller (Eds.), Teaching Children English: from research to practice, Reading: Garnet Publishing Ltd, 115-135.

Gordon (2008): Tomas Gordon, Kako biti uspešan nastavnik, Beograd: Kreativni centar.

Hattie (2015): John Hattie, The Applicability of Visible Learning to Higher Education, Scholarship of Teaching and Learning in Psychology, 1 (1), 79-91. http://dx.doi. org/10.1037/st10000021

Hébert, Hartley (2006): Yvonne Hébert, William J. Hartley, Personalised Learning and Changing Conceptions of Childhood and Youth, In: Schooling for Tomorrow: Personalising Education, Paris: Organisation for Economic Co-operation and Development (OECD) \& Centre for Educational Research and Innovation (CERI), 63-73. Retrieved on March 13, 2018 from http://www.oecd-ilibrary.org/education/personalisingeducation_9789264036604-en.

Kopas-Vukašinović (2014): Emina Kopas-Vukašinović, Student Initiative in the Classroom as a Prerequisite for the Development of University Education System, In: Ti- 
bor J. Karlovitz (Ed.), Some Current Issues in Pedagogy, Komarno: International Research Institute, 37-50.

Kopas-Vukašinović, Golubović-Ilić (2017): Emina Kopas-Vukašinović, Irena Golubović-Ilić, Attitudes of Students about the Effects of Ambient Teaching, In: Silva Bratož (Ed.), Dimensins of Contemporary Learning Environments, Koper (Slovenia): University of Primorska, Faculty of Education, 253-266.

McLaughlin (2012): Lou McLaughlin, Young Learner Teacher Cognition and Teacher Training, International House Journal of Education and Development, 33, n.p. Retrieved on March 13, 2018 from http://ihjournal.com/young-learner-teacher-cognitionand-teacher-training-by-lou-mclaughlin.

Milovanović, Kopas-Vukašinović (2014): Radmila Milovanović, Emina Kopas-Vukašinović, Percepcije kreativnosti i kreativni potencijali budućih vaspitača i učitelja, Zbornik Instituta za pedagoška istraživanja, 46 (1), 181-199. DOI: 10.2298/ZIPI1401181M

Mirkov (2013): Snežana Mirkov, Učenje - zašto i kako: pristupi u proučavanju činilaca koji deluju na učenje, Beograd: Institut za pedagoška istraživanja.

Savić (2012): Vera Savić, Razvoj modula Engleski jezik - Metodika nastave engleskog jezika na mlađem uzrastu: izazovi i perspektive, U: Ilijana Čutura, Vesna Trifunović (ur.), Škola kao činilac razvoja nacionalnog i kulturnog identiteta i proevropskih vrednosti, tom II, Jagodina: Pedagoški fakultet u Jagodini, 483-498.

Spasić, Juranić, Jelić, Bošnjak, Rakonjac (2000): Žarko Spasić, Ivan Juranić, Miloš Jelić, Srđan Bošnjak, Ivan Rakonjac, Podizanje kvaliteta nastave i istraživanja, Beograd: Zajednica univerziteta Srbije. Retrieved on June 5, 2019, from http://www.chem.bg.ac. rs/ ijuranic/QualityEnh.pdf.

Standardi i smjernice za osiguranje kvaliteta u Evropskom području visokog obrazovanja (2005): Helsinki: Evropsko udruženje za osiguranje kvaliteta u visokom obrazovanju. http://www.enqa.eu/indirme/esg/ESG_loc.pdf.

The Bologna Process 2020 - The European Higher Education Area in the New Decade (2009): Communique of the conference of European ministers responsible for higher education, Leuven and Louvain-la-Neuve, 28-29 April 2009. https://www.eurashe.eu/library/modernising-phe/Bologna_2009_Leuven-Communique.pdf

UNESCO (2004): Changing Teaching Practices, Using Curriculum Differentiation to Respond to Students' Diversity, Paris: the United Nations Educational, Scientific and Cultural Organization. Retrieved on March 13, 2018 from http://unesdoc.unesco.org/ images/0013/001365/136583e.pdf 


\section{Емина М. Копас-Вукашиновић}

Универзитет у Крагујевцу

Факултет педагошких наука у Јагодини

Катедра за друштвено-хуманистичке науке

\section{Вера М. Савић}

Катедра за филолошке науке

\section{КРЕИРАЮЕ САДРЖАЈА КУРИКУЛУМА КАО ФАКТОР ОСТВАРИВАЮА КВАЛИТЕТНОГ ОБРАЗОВАҢА}

Резиме: Способност креирања садржаја курикулума захтева развој савремених стратегија подучавања и учења, у контексту унапређивања способности резоновања, истраживања, учења кроз активности и изграђивања сопствених креативних потенцијала. Циљ рада је био да се утврди да ли будући васпитачи препознају значај креирања наставних садржаја (КНС) у образовном процесу. Истраживање је спроведено са мастер студентима на смеру Васпитач у предшколским установама $(\mathrm{N}=53)$, на Факултету педагошких наука Универзитета у Крагујевцу, Јагодина, Србија. Подаци су прикупљени применом интервјуа са студентима, у фокус групама. Ставови испитаника о квалитету универзитетске наставе јасно указују на њихову потребу и спремност да креирају садржаје курикулума који ће омогућити ефикаснију наставу, као и на значај КСН за унапређивање квалитета образовања.

Кључне речи: кооперативно учење, тематско повезивање садржаја, одговарајући фидбек, стандарди у високом образовању, систем управљања знањем. 